\title{
Genetic Relationships in an International Collection of Puccinia horiana Isolates Based on Newly Identified Molecular Markers and Demonstration of Recombination
}

\author{
M. De Backer, P. Bonants, K. F. Pedley, M. Maes, I. Roldan-Ruiz, E. Van Bockstaele, K. Heungens, and T. van der Lee
}

First, fourth, fifth, sixth, and seventh authors: Institute for Agricultural and Fisheries Research (ILVO), Plant Sciences Unit, Burg. Van Gansberghelaan 96 bus 2, 9820 Merelbeke, Belgium; first and sixth authors: Ghent University, Faculty of Bioscience Engineering, Department of Plant Production, Coupure links 653, 9000 Ghent; second and eighth authors: Plant Research International, Biointeractions and Plant Health, Droevendaalsesteeg 1, 6708PB Wageningen; and third author: United States Department of Agriculture-Agricultural Research Service, Foreign Disease-Weed Science Research Unit, 1301 Ditto Ave., Ft. Detrick, MD 21702.

Accepted for publication 6 June 2013.

\begin{abstract}
De Backer, M., Bonants, P., Pedley, K. F., Maes, M., Roldan-Ruiz, I., Van Bockstaele, E., Heungens, K., and van der Lee, T. 2013. Genetic relationships in an international collection of Puccinia horiana isolates based on newly identified molecular markers and demonstration of recombination. Phytopathology 103:1169-1179.

The obligate biotrophic pathogen Puccinia horiana is the causal agent of chrysanthemum white rust. Although $P$. horiana is a quarantine organism, it has been able to spread to most chrysanthemum-producing regions in the world since the 1960s; however, the transfer routes are largely obscure. An extremely low level of allelic diversity was observed in a geographically diverse set of eight isolates using complexity reduction of polymorphic sequences (CRoPS) technology. Only 184 of the 16,196 contigs $(1.1 \%)$ showed one or more single-nucleotide polymorphisms (SNPs). Thirty-two SNPs and one simple-sequence repeat were translated into molecular markers and used to genotype 45 isolates

originating from North and South America, Asia, and Europe. In most cases, phylogenetic clustering was related to geographic origin, indicating local establishment. The European isolates mostly grouped in two major populations that may relate to the two historic introductions previously reported. However, evidence of recent geographic transfer was also observed, including transfer events between Europe and South America and between Southeast Asia and Europe. In contrast with the presumed clonal propagation of this microcyclic rust, strong indications of marker recombination were observed, presumably as a result of anastomosis, karyogamy, and somatic meiosis. Recombination and transfer also explain the geographic dispersal of specific markers. A near-to-significant correlation between the genotypic data and previously obtained pathotype data was observed and one marker was associated with the most virulent pathotype group. In combination with a fast SNP detection method, the markers presented here will be helpful tools to further elucidate the transfer pathways and local survival of this pathogen.
\end{abstract}

Chrysanthemum white rust is caused by Puccinia horiana Henn. and is one of the most important diseases in chrysanthemum production. $P$. horiana is a microcyclic rust that can infect $>10$ different chrysanthemum species, of which Chrysanthemum $\times$ morifolium is economically the most important one. After the first detection of $P$. horiana in Japan in $1895(24,25)$, it was also reported in China and South Africa some time before 1963 (43). In 1963, $P$. horiana was introduced in England on plants originating from Japan (3), followed by introductions in continental Europe in 1964 on cuttings originating from South Africa $(3,17,43)$. Currently, $P$. horiana is present in most chrysanthemum-producing areas throughout the world $(13,54)$. It is classified as a quarantine pathogen in Europe, Africa, and America (13) and also listed as a regulated pest by the International Plant Protection Convention.

Symptoms appear as chlorotic spots, 7 to 10 days postinfection (dpi) at an optimal temperature of 17 to $20^{\circ} \mathrm{C}$; subsequently, teliospores develop 14 to $18 \mathrm{dpi}$ on the abaxial side of the leaves (17). These teliospores can germinate without a period of dormancy to form a promycelium on which two binucleate basidio-

Corresponding author: K. Heungens; E-mail address: kurt.heungens@ilvo.vlaanderen.be

* The $\boldsymbol{e}$-Xtra logo stands for "electronic extra" and indicates that the online version contains two supplementary figures.

http://dx.doi.org/10.1094/PHYTO-01-13-0007-R

(c) 2013 The American Phytopathological Society spores are produced $(28,30,31)$. Basidiospores are the mobile and infective propagules that are easily spread by wind and can infect plants in neighboring fields (58), giving rise to a binucleate vegetative mycelium $(30,31)$. Because $P$. horiana is a selffertilizing rust, the basidiospores are genetically uniform unless mutation or anastomosis and subsequent recombination between different genotypes occurs $(41,45)$.

The presence of different pathotypes of the pathogen was reported on several occasions $(11,49,55,57)$. However, the full complexity of the pathosystem was shown in a comprehensive study only recently, in which a collection of 22 isolates, covering a broad geographic range, was tested on a set of 36 chrysanthemum cultivars (10). Based on the gene-for-gene concept (18), at least seven avirulence genes were postulated in this pathosystem.

Up to now, no single report on the genetic diversity of an international collection of $P$. horiana isolates has been published. However, this information is of special relevance to understand the dynamics of $P$. horiana populations throughout the world, given the extensive international trade of chrysanthemum planting material and cut flowers. Analyses of genetic diversity in fungal populations have been frequently based on the use of amplified fragment length polymorphism (AFLP). AFLP allows the rapid screening of different loci within a genome without the need of sequence information for primer design but, because it does not allow selective marker amplification in a background of contaminating plant material and microorganisms, it is less suitable for the analysis of obligate biotrophs such as $P$. horiana, for which 
harvest of free-living spores is either not possible or very difficult $(36,51)$. Markers such as single-nucleotide polymorphisms (SNPs) or simple-sequence repeats (SSRs) require sequence information but they are locus specific, allowing the amplification of fungal sequences in a background of plant DNA. SNPs have lower mutation rates than SSR markers, making them more suitable for population genetics in distantly related isolates $(6,37)$. For the development of SNP markers in non-model organisms such as $P$. horiana, sequencing of randomly distributed AFLP fragments can be used $(37,39)$. This approach combines the power of genome complexity reduction of AFLP with high-throughput nextgeneration sequencing, and has been described as complexity reduction of polymorphic sequences (CRoPS) (48).

In this study, we developed a set of molecular markers to determine the genetic variability within a newly established comprehensive worldwide collection of isolates of $P$. horiana. In a first step, SNP mining was performed using the CRoPS technology on a set of isolates representing different pathotypes, as determined by De Backer et al. (10). In a second step, specific polymerase chain reaction (PCR) primers were developed to amplify the SNP-containing fragments, allowing SNP calling after sequencing. These primers were used to determine the genotypic variability of 45 isolates of $P$. horiana. The data were used to assess diversity in the set of isolates in our worldwide collection and to verify the occurrence and relative importance of recombination in the formation of new genotypes. Based on the genetic relations and population structure, the patterns of geographic transfer of the pathogen and the endemic or exotic character of isolates in different regions were analyzed. The relationship between these genotypic data and the pathotype data obtained by De Backer et al. (10) were determined, and the possibility for the development of pathotype-specific SNP markers is discussed.

\section{MATERIALS AND METHODS}

$\boldsymbol{P}$. horiana isolates. Forty-nine isolates of $P$. horiana were collected from commercially grown Chrysanthemum $\times$ morifolium plants between 2003 and 2010 (Table 1). Isolates were mainly selected based on geographic distribution, including Europe, Asia, and North and South America, except for most of the isolates from the Netherlands (Table 1, NL1 and NL3-6), which cannot be considered field isolates because they were resampled from a mixed culture in a biosecurity facility. This mixed culture included local isolates as well as isolates from customs interceptions (Table 1). Belgian isolates were collected during multiple years (2003 to 2009). Some isolates collected after 2005 were selected based on potential pathotype differences, because they were mainly collected from cultivars previously reported as resistant. Single-pustule isolates were established for all isolates, after which they were individually maintained by 3-weekly transfer onto fresh cuttings, as described previously $(1,10)$. The pathotype information of 22 of these isolates was obtained from De Backer et al. (10). The pathotype of four isolates (Table 1) was determined in this study, using the methods of De Backer et al. (10). From a total of 45 isolates, sufficient amounts of DNA could be obtained for genotyping (see below). From four of the isolates with a known pathotype, no genotypic data could be obtained because the isolates were no longer available after the pathotyping study. Inoculations and pathogen maintenance were conducted in laboratories and growth chambers with appropriate biosafety levels.

CRoPS analysis. Eight isolates were selected for the CRoPS analysis, mainly based on their differential pathotype profiles (Table 1). P. horiana genomic DNA (gDNA) was extracted from basidiospores instead of pustules to avoid contaminating plant DNA. Basidiospores were collected using a modified version of the harvesting setup described by Alaei et al. (1). Infected chrysanthemum leaves were attached to the lid of 10-cm Petri dishes with the telia pointing downward. The leaves were misted with demineralized water using a Preval Sprayer (Yonkers, NY) and incubated at $17^{\circ} \mathrm{C}$ in the dark for a maximum of $14 \mathrm{~h}$. Basidiospore "prints" on the bottom of the Petri dishes were verified microscopically at $\times 100$ magnification for contaminating spores such as those from Malassezia restricta (1). For each Petri dish, basidiospores were collected using $1 \mathrm{ml}$ of $0.1 \%$ Igepal CA630 (a surfactant) in water (Sigma-Aldrich, St. Louis). Spores were collected in $1.5-\mathrm{ml}$ microcentrifuge tubes and concentrated by centrifugation and careful removal of most of the supernatant. Basidiospores harvested from up to 10 Petri dishes per isolate were combined in a single pellet and stored at $-20^{\circ} \mathrm{C}$ until DNA extraction. gDNA was extracted from the basidiospores using a cetyltrimethylammonium bromide extraction protocol, as described by Alaei et al. (1). DNA was quantified and its quality checked using a Nanodrop spectrophotometer (Thermo Scientific, DE) and gel electrophoresis. It was stored at $-20^{\circ} \mathrm{C}$ until further analysis.

The CRoPS analysis was performed by Keygene NV (The Netherlands). gDNA (10 to $50 \mathrm{ng}$ ) was used to generate AFLP fragments with restriction enzymes EcoRI and MseI. Fragments were selectively amplified with a single primer combination consisting of the EcoRI primer without selective bases and the MseI primer with one selective base (MseI-G) as described by Vos et al. (51). The AFLP primers were extended with 4-nucleotidelong sample identification tags for a correct assignment of the sequences to the corresponding samples after 454 sequencing. A sequence library of the AFLP fragments was prepared based on the Roche GS FLX Titanium protocol and sequenced on a GS FLX Titanium sequencing instrument (Roche, Basel, Switzerland).

SNP mining and marker development. Sequence reads from the CRoPS analysis were quality clipped and assembled in contigs which were aligned to determine putative polymorphisms, including SNPs, indels, and microsatellites using the Keygene proprietary automated SNP mining tool. This tool also masked the chloroplast and mitochondrial reads in the assembly. Contigs containing putative polymorphisms were manually selected for further analysis if (i) they had a minimum length of 100 nucleotides, (ii) 10 or more reads were included in the alignment, (iii) sequences from at least four of the eight isolates were available, (iv) at least two reads per sample contained the polymorphism, and (v) each allele was present in 10 to $90 \%$ of the reads. Candidate SNPs or other polymorphisms had to be located at a minimum distance of 18 nucleotides from the $5^{\prime}$ and $3^{\prime}$ end of the fragment to allow developing primers flanking the polymorphism. Such primers were developed using CLC DNA Workbench (CLCBio, Denmark). Primer pairs were tested using two or three candidate differential isolates and the optimum annealing temperature $\left(\mathrm{T}_{\mathrm{an}}\right)$ of 45 to $60^{\circ} \mathrm{C}$ was determined. The sequences of the contigs that contained putative polymorphisms were used in a BLASTn search against the Puccinia Group Database (http:// www.broadinstitute.org) and BLASTn and BLASTx searches against the GenBank database using the default settings.

PCR amplification was performed in a GeneAmp PCR System 9700 PE thermocycler (Applied Biosystems, CA). Fragmentspecific primer sequences that were used in the PCR reactions as well as their optimal annealing temperatures are listed in Table 2. PCR reactions were performed in $50 \mu \mathrm{l}$ containing PCR reaction buffer $\left(50 \mathrm{mM}\right.$ Tris/ $\mathrm{HCl}, 10 \mathrm{mM} \mathrm{KCl}, 5 \mathrm{mM}\left(\mathrm{NH}_{4}\right)_{2} \mathrm{SO}_{4}$, and $2.0 \mathrm{mM} \mathrm{MgCl}_{2}, \mathrm{pH} 8.3$ ), $0.2 \mathrm{mM}$ of each dNTP, $0.2 \mu \mathrm{M}$ of forward and reverse primers, and FastStart Taq DNA Polymerase at $0.02 \mathrm{U} / \mu \mathrm{l}$. Per PCR reaction, $5 \mu \mathrm{l}$ of 50 -fold diluted wholegenome amplification product (see below) was added. The cycle parameters were an initial preheating at $94^{\circ} \mathrm{C}$ for $2 \mathrm{~min}$ and 35 cycles of denaturation at $94^{\circ} \mathrm{C}$ for $30 \mathrm{~s}$, annealing at 46 or $54^{\circ} \mathrm{C}$ (depending on primer combination) (Table 2) for $45 \mathrm{~s}$, and extension at $72^{\circ} \mathrm{C}$ for $45 \mathrm{~s}$. A final extension step at $72^{\circ} \mathrm{C}$ for 
7 min finished the reaction, after which the samples were cooled to $4^{\circ} \mathrm{C}$. PCR products were checked by loading $10 \mu \mathrm{l}$ on an ethidium-bromide-containing agarose gel $(2.0 \%$ agarose in $0.5 \times$ Tris-acetate-EDTA) buffer. PCR products were prepared for Sanger sequencing using the BigDye Terminator v3.1 Cycle Sequencing Kit (Applied Biosystems) followed by an ethanol precipitation step. Samples were loaded on a 3730XL DNA sequencer (Applied Biosystems) for capillary electrophoresis and genetic analysis.

Genotyping using SNP markers. The SNP and SSR markers developed using the CRoPS data were used to genotype the 45 $P$. horiana isolates listed as such in Table 1 . Preliminary assays determined that the primer pairs flanking each marker only amplified the $P$. horiana targets when using DNA samples from

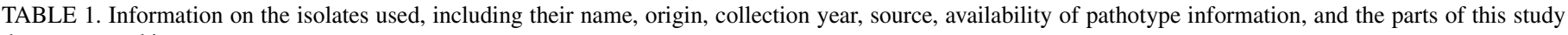
they were used in ${ }^{\mathrm{a}}$

\begin{tabular}{|c|c|c|c|c|c|c|c|c|}
\hline $\begin{array}{l}\text { Isolate } \\
\text { code }\end{array}$ & Isolate name & Origin & $\begin{array}{c}\text { Collection } \\
\text { year }\end{array}$ & Source $^{b}$ & $\begin{array}{l}\text { Pathotype } \\
\text { known }\end{array}$ & AFLP & CRoPS & SNP \\
\hline BE1 & Ph 301 & Belgium, Ghent region & 2003 & ILVO & $X^{c}$ & $X$ & $\mathrm{X}$ & $\mathrm{X}$ \\
\hline BE2 & Ph 307 & Belgium, Ghent region & 2003 & ILVO & $X^{c}$ & $\ldots$ & $\ldots$ & $\ldots$ \\
\hline BE3 & $\mathrm{Ph} 308$ & Belgium, Ghent region & 2003 & ILVO & $\mathrm{X}^{\mathrm{c}}$ & $\mathrm{X}$ & $\ldots$ & $\mathrm{X}$ \\
\hline BE4 & $\mathrm{Ph} 522$ & Belgium, Ghent region & 2005 & ILVO & $\mathrm{X}^{\mathrm{c}}$ & $\mathrm{X}$ & $\ldots$ & $\mathrm{X}$ \\
\hline BE5 & $\mathrm{Ph} 707$ & Belgium, Mechelen region & 2007 & Gediflora & $\mathrm{X}^{\mathrm{c}}$ & $\mathrm{X}$ & $\mathrm{X}$ & $\mathrm{X}$ \\
\hline BE6 & $\mathrm{Ph} 801$ & Belgium, Mechelen region & 2008 & Gediflora & $\mathrm{X}^{\mathrm{c}}$ & $\ldots$ & $\ldots$ & $\mathrm{X}$ \\
\hline BE7 & $\mathrm{Ph} 312$ & Belgium, Ghent region & 2003 & ILVO & $\ldots$ & $\ldots$ & $\ldots$ & $\mathrm{X}$ \\
\hline BE8 & $\mathrm{Ph} 515$ & Belgium, Ghent region & 2005 & ILVO & $\ldots$ & $\ldots$ & $\ldots$ & $\mathrm{X}$ \\
\hline BE9 & $\mathrm{Ph} 520$ & Belgium, Ghent region & 2005 & ILVO & $\ldots$ & $\ldots$ & $\ldots$ & $\mathrm{X}$ \\
\hline BE10 & $\mathrm{Ph} 531$ & Belgium, Ghent region & 2005 & ILVO & $\ldots$ & $\ldots$ & $\ldots$ & $\mathrm{X}$ \\
\hline BE11 & $\mathrm{Ph} 712$ & Belgium, Ghent region & 2007 & PCS & $\ldots$ & $\ldots$ & $\ldots$ & $\mathrm{X}$ \\
\hline BE12 & $\mathrm{Ph} 724$ & Belgium, Ghent region & 2007 & PCS & $\ldots$ & $\ldots$ & $\ldots$ & $\mathrm{X}$ \\
\hline BE13 & $\mathrm{Ph} 804$ & Belgium, Mechelen region & 2008 & Gediflora & $\ldots$ & $\ldots$ & $\ldots$ & $X$ \\
\hline BE14 & $\mathrm{Ph} 805$ & Belgium, Mechelen region & 2008 & Gediflora & $\ldots$ & $\ldots$ & $\ldots$ & $\mathrm{X}$ \\
\hline BE15 & $\mathrm{Ph} 902$ & Belgium, Mechelen region & 2007 & Gediflora & $\ldots$ & $\ldots$ & $\ldots$ & $\mathrm{X}$ \\
\hline $\mathrm{CO} 1$ & $\mathrm{Ph}$ Colombia 2 & Colombia, Boyaca region & 2008 & ICA & $\mathrm{X}^{\mathrm{c}}$ & $\ldots$ & $\ldots$ & $\mathrm{X}$ \\
\hline $\mathrm{CO} 2$ & $\mathrm{Ph}$ Colombia 3 & Colombia, Cundinamarca region & 2008 & ICA & $\mathrm{X}^{\mathrm{c}}$ & $\ldots$ & $\ldots$ & $\mathrm{X}$ \\
\hline $\mathrm{CO} 3$ & $\mathrm{Ph}$ Colombia 1 & Colombia, Boyaca region & 2008 & ICA & $\ldots$ & $\ldots$ & $\ldots$ & $\mathrm{X}$ \\
\hline $\mathrm{CN} 1^{\mathrm{e}}$ & Ph China 1 & China & 2010 & Deliflor & $\ldots$ & $\ldots$ & $\ldots$ & $\mathrm{X}$ \\
\hline FR1 & Ph CWR 07.B18 & France & 2007 & BBV & $\mathrm{X}^{\mathrm{c}}$ & $\ldots$ & $\ldots$ & $\mathrm{X}$ \\
\hline FR2 & Ph CWR 08.A4 & France & 2008 & BBV & $\mathrm{X}^{\mathrm{c}}$ & $\ldots$ & $\ldots$ & $\mathrm{X}$ \\
\hline FR3 & Ph CWR 07.A20 & France & 2007 & BBV & $\ldots$ & $\ldots$ & $\ldots$ & $\mathrm{X}$ \\
\hline GB1 & Ph Redhill UK & United Kingdom & 2005 & FERA & $\mathrm{X}^{\mathrm{c}}$ & $\mathrm{X}$ & $\mathrm{X}$ & $\mathrm{X}$ \\
\hline GB2 & Ph SGP UK & United Kingdom & 2005 & FERA & $\mathrm{X}^{\mathrm{c}}$ & $\mathrm{X}$ & $\ldots$ & $\mathrm{X}$ \\
\hline GB3 & Ph Spalding UK & United Kingdom & 2005 & FERA & $\mathrm{X}^{\mathrm{c}}$ & $\mathrm{X}$ & $\mathrm{X}$ & $\mathrm{X}$ \\
\hline JP1 & Ph Japan 2 & Japan, Hiroshima region & 2008 & Deliflor & $\mathrm{X}^{\mathrm{c}}$ & $\mathrm{X}$ & $\mathrm{X}$ & $\mathrm{X}$ \\
\hline JP2 & Ph Japan 3 & Japan, Hiroshima region & 2008 & Deliflor & $\mathrm{X}^{\mathrm{c}}$ & $\mathrm{X}$ & $\mathrm{X}$ & $\mathrm{X}$ \\
\hline JP3 & Ph Japan 13 & Japan, Tochigi region & 2009 & Deliflor & $\mathrm{X}^{\mathrm{c}}$ & $\ldots$ & $\ldots$ & $\mathrm{X}$ \\
\hline JP4 & Ph Japan 12 & Japan, Hiroshima region & 2009 & RVZ & $\mathrm{X}$ & $\ldots$ & $\ldots$ & $\mathrm{X}$ \\
\hline LK1 & Ph Sri Lanka1 & Sri Lanka, Nuwara Eliya region & 2009 & RVZ & $\mathrm{X}$ & $\ldots$ & $\ldots$ & $\mathrm{X}$ \\
\hline MY1 & Ph Malaysia 2 & Malaysia, Cameron Highlands region & 2008 & Dekker Breeding & $\mathrm{X}^{\mathrm{c}}$ & $\ldots$ & $\ldots$ & $\mathrm{X}$ \\
\hline MY2 & $\mathrm{Ph}$ Malaysia 3 & Malaysia & 2008 & Dekker Breeding & $\mathrm{X}^{\mathrm{c}}$ & $\ldots$ & $\ldots$ & $\ldots$ \\
\hline MY3 & $\mathrm{Ph}$ Malaysia 1 & Malaysia & 2008 & Deliflor & $\ldots$ & $\ldots$ & $\ldots$ & $\mathrm{X}$ \\
\hline MY4 & $\mathrm{Ph}$ Malaysia 8 & Malaysia & 2008 & Dekker Breeding & $\ldots$ & $\ldots$ & $\ldots$ & $\mathrm{X}$ \\
\hline MY5 & $\mathrm{Ph}$ Malaysia 4 & Malaysia & 2008 & Dekker Breeding & $\ldots$ & $\ldots$ & $\ldots$ & $\mathrm{X}$ \\
\hline MY6 & Ph Malaysia 6 & Malaysia & 2008 & Dekker Breeding & $\ldots$ & $\ldots$ & $\ldots$ & $\mathrm{X}$ \\
\hline MY7 & Ph Malaysia 7 & Malaysia & 2008 & Dekker Breeding & $\ldots$ & $\ldots$ & $\ldots$ & $\mathrm{X}$ \\
\hline $\mathrm{NL} 1^{\mathrm{d}}$ & $\mathrm{Ph}$ NL 1 & The Netherlands & 2006 & $\mathrm{PD}$ & $X^{c}$ & $\ldots$ & $\ldots$ & $\ldots$ \\
\hline NL2 & Ph NL 802 & The Netherlands & 2008 & RVZ & $X^{c}$ & $\ldots$ & $\ldots$ & $X$ \\
\hline $\mathrm{NL}^{\mathrm{d}}$ & Ph PD 20 & The Netherlands & 2008 & $\mathrm{PD}$ & $\mathrm{X}$ & $\mathrm{X}$ & $\mathrm{X}$ & $\mathrm{X}$ \\
\hline $\mathrm{NL}^{\mathrm{d}}$ & Ph PD 13 & The Netherlands & 2008 & PD & $\ldots$ & $\ldots$ & $\ldots$ & $\mathrm{X}$ \\
\hline $\mathrm{NL5}^{\mathrm{d}}$ & Ph PD 28 & The Netherlands & 2008 & PD & $\ldots$ & $\ldots$ & $\ldots$ & $\mathrm{X}$ \\
\hline NL6 $^{\mathrm{d}}$ & $\mathrm{Ph}$ PD 36 & The Netherlands & 2008 & $\mathrm{PD}$ & $\mathrm{X}$ & $\ldots$ & $\ldots$ & $\ldots$ \\
\hline PL1 & $\mathrm{Ph}$ Poland & Poland & 2006 & INSAD & $X^{c}$ & $\mathrm{X}$ & $\mathrm{X}$ & $\mathrm{X}$ \\
\hline US1 & Ph USA 1 & United States, Massachusetts & 2008 & USDA-APHIS-PPQ & $\mathrm{X}^{\mathrm{c}}$ & $\ldots$ & $\ldots$ & $\mathrm{X}$ \\
\hline $\mathrm{US} 2^{\mathrm{e}}$ & Ph USA CA1-10 & United States, California & 2010 & USDA-ARS-NAA & $\ldots$ & $\ldots$ & $\ldots$ & $\mathrm{X}$ \\
\hline $\mathrm{US}^{\mathrm{e}}$ & Ph USA CT1-10 & United States, Connecticut & 2010 & USDA-ARS-NAA & $\ldots$ & $\ldots$ & $\ldots$ & $\mathrm{X}$ \\
\hline US4 $4^{\mathrm{e}}$ & Ph USA MD1-10 & United States, Maryland & 2010 & USDA-ARS-NAA & $\ldots$ & $\ldots$ & $\ldots$ & $\mathrm{X}$ \\
\hline $\mathrm{US5}^{\mathrm{e}}$ & Ph USA PA1-10 & United States, Pennsylvania & 2010 & USDA-ARS-NAA & $\ldots$ & $\ldots$ & $\ldots$ & $\mathrm{X}$ \\
\hline
\end{tabular}

${ }^{\mathrm{a}} \mathrm{AFLP}=$ amplified fragment length polymorphism, CRoPS = complexity reduction of polymorphic sequences, and SNP $=$ single-nucleotide polymorphism profile known.

b Samples obtained via ILVO = Institute for Agricultural and Fisheries Research, Merelbeke, Belgium and Gediflora, Staden-Oostnieuwkerke, Belgium; ICA = Instituto Colombiano Agropecuario, Bogota, Colombia; Vegenov-BBV = Bretagne Biotechnologie Végétale, Saint Pol de Léon, France; FERA (formerly CSL $)=$ The Food and Environment Research Agency, York, United Kingdom, Deliflor, Maasdijk, The Netherlands, and Dekker Breeding, Hensbroek, The Netherlands; PD = Plant Protection Service, Wageningen, The Netherlands; RVZ = Royal Van Zanten, Rijsenhout, The Netherlands; INSAD = Research Institute of Pomology and Floriculture, Skierniewice, Poland; USDA-APHIS-PPQ = United States Department of Agriculture-Animal and Plant Health Inspection Service-Plant Protection and Quarantine; and USDA-ARS-NAA = United States Department of Agriculture-Agricultural Research Service-North Atlantic Area.

c Isolates included in pathotype study by De Backer et al. (10).

${ }^{d}$ The geographic origin of the isolates obtained from PD is not known but they included custom interceptions (P. Van Rijswick, Plant Protection Service, The Netherlands, personal communication). Because they were maintained in a mixed culture with other isolates, there was an increased probability of recombination among these isolates.

e Isolates for which only DNA is available (so no pathotype tests can/could be performed). 
infected plant samples. This allowed the use of pustules instead of basidiospores as starting material for DNA preparation. Fresh pustules, containing mostly teliospores, were collected from chrysanthemum cuttings that had been inoculated 3 weeks earlier. Fresh pustules ( 5 to $30 \mathrm{mg}$ ) were frozen in liquid nitrogen and ground with a pestle in a microcentrifuge tube before DNA extraction using the Invisorb Spin Plant Mini Kit (Invitek, Germany) following the manufacturer's instructions but without the optional RNase step. DNA was eluted in $50 \mu \mathrm{l}$ of the kit's buffer $\mathrm{D}$ and stored at $-20^{\circ} \mathrm{C}$.

TABLE 2. Amplified fragment length polymorphism (AFLP) fragments containing polymorphisms and corresponding primers for PCR amplification of the region surrounding the polymorphism ${ }^{\mathrm{a}}$

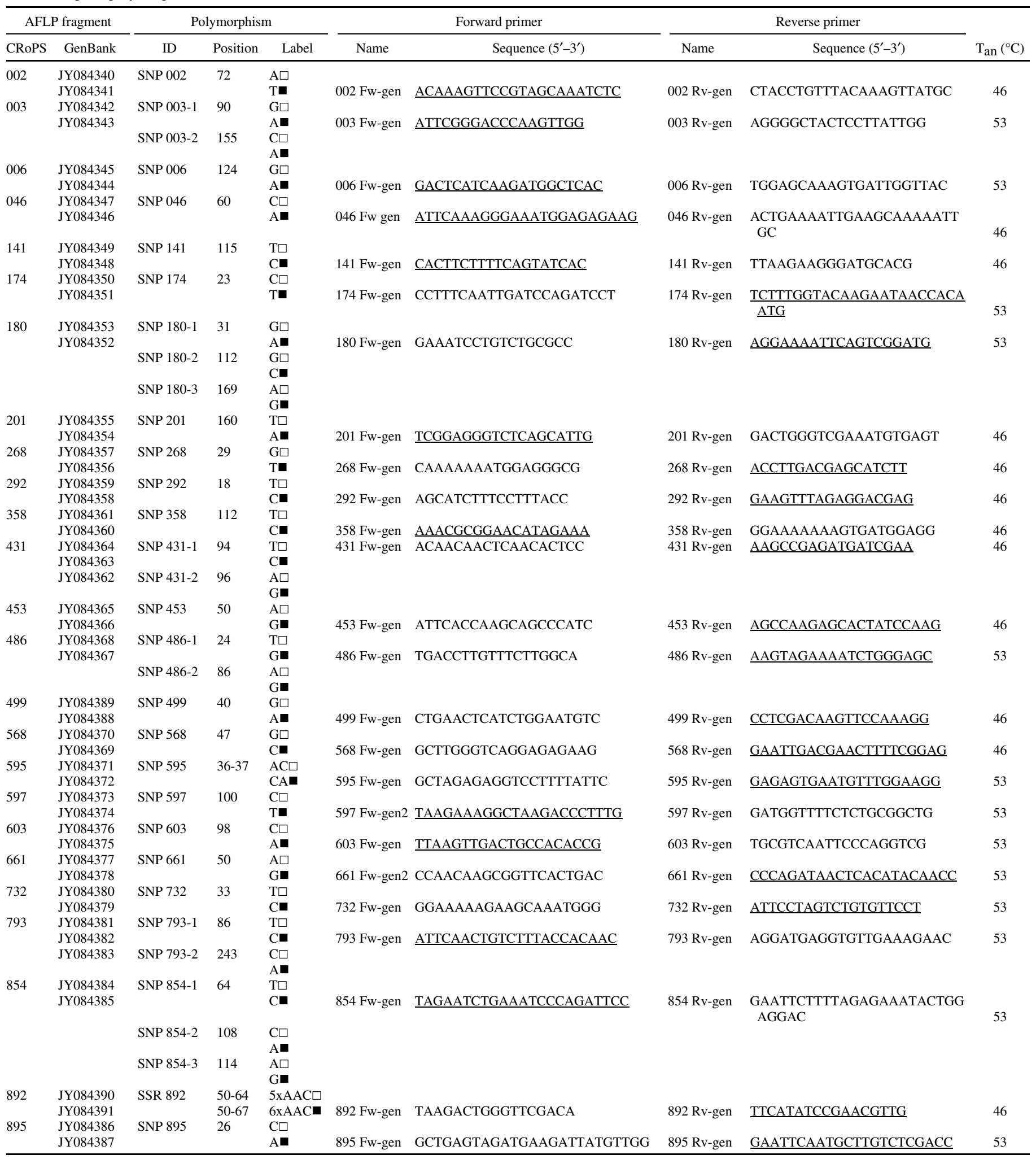

${ }^{a}$ For each fragment, the complexity reduction of polymorphic sequences (CRoPS) fragment number, GenBank accession number, and forward and reverse primers and optimal annealing temperature $\left(\mathrm{T}_{\mathrm{an}}\right)$ are listed. Primers used for the sequencing reaction are underlined. For each polymorphism, the identification code and the position of the polymorphism within the fragment is listed. Each polymorphism is presented in its binary state, either as an empty square ( $\square$ ) for the value "0" or a filled square (ם) for the value "1" as used in Figure 1. 
Considering the large amount of DNA required to optimize and test all developed primer combinations, a whole-genome amplification step was introduced for all the DNA samples using the Illustra GenomiPhi V2 DNA Amplification Kit (GE Healthcare, UK) following the manufacturer's instructions. The amplification products were stored at $-20^{\circ} \mathrm{C}$ until further processing.

SNP data analysis. SNP and SSR data were converted to binary data by assigning the value " 0 " to the most-frequent allele among all isolates and the value " 1 " to the least-frequent allele (Table 2). From the binary data, similarity matrices were calculated using the simple matching coefficient (23). Cluster analysis was done with the unweighted pair group method using arithmetic averages (UPGMA) using the Bionumerics software (Applied Maths, Belgium). Low bootstrap values were expected due to the relatively low number of markers and isolates. Therefore, the cophenetic correlation coefficients between the dendrogram-derived similarities and the original matrix of genetic similarities were calculated for each cluster to verify the agreement between both matrices (16). The resulting dendrogram was compared with those obtained with neighbor-joining and maximum-likelihood methods.

Genetic structure in the collection was investigated with the Bayesian approach implemented in STRUCTURE v2.3.4 $(15,44)$ using diploid data as input. The number of genetic clusters (K) was estimated using the admixture model with correlated allele frequencies and without any prior information as to the origin of the individual isolates. Simulations were run for K ranging from 1 to 15 with a burn-in of 50,000 iterations of the Markov chain, followed by a run length of 500,000 iterations. For each model, the ln likelihood $[\mathrm{L}(\mathrm{K})]$ was determined for 20 parallel Markov chains. The most likely value of $\mathrm{K}$ was determined based on the mean $\mathrm{L}(\mathrm{K})>20$ runs for each $\mathrm{K}(44)$ and the second-order rate of change of the likelihood function with respect to $K(\Delta K)$ (14).

Recombination and pathotype correlation analysis. For each genotype, we determined whether it could be a recombinant of any two other genotypes in our collection. A genotype was considered a potential recombinant when it contained all the alleles shared by the candidate parents and a combination of alleles that are different between the candidate parents. Recombination was investigated because specific genotypes shared rare marker alleles with each of two other genotypes. The probability of the alternative hypothesis of repeated emergence of these specific SNPs is extremely low. The number of combinations in which each genotype can be a potential parental genotype of each other genotype

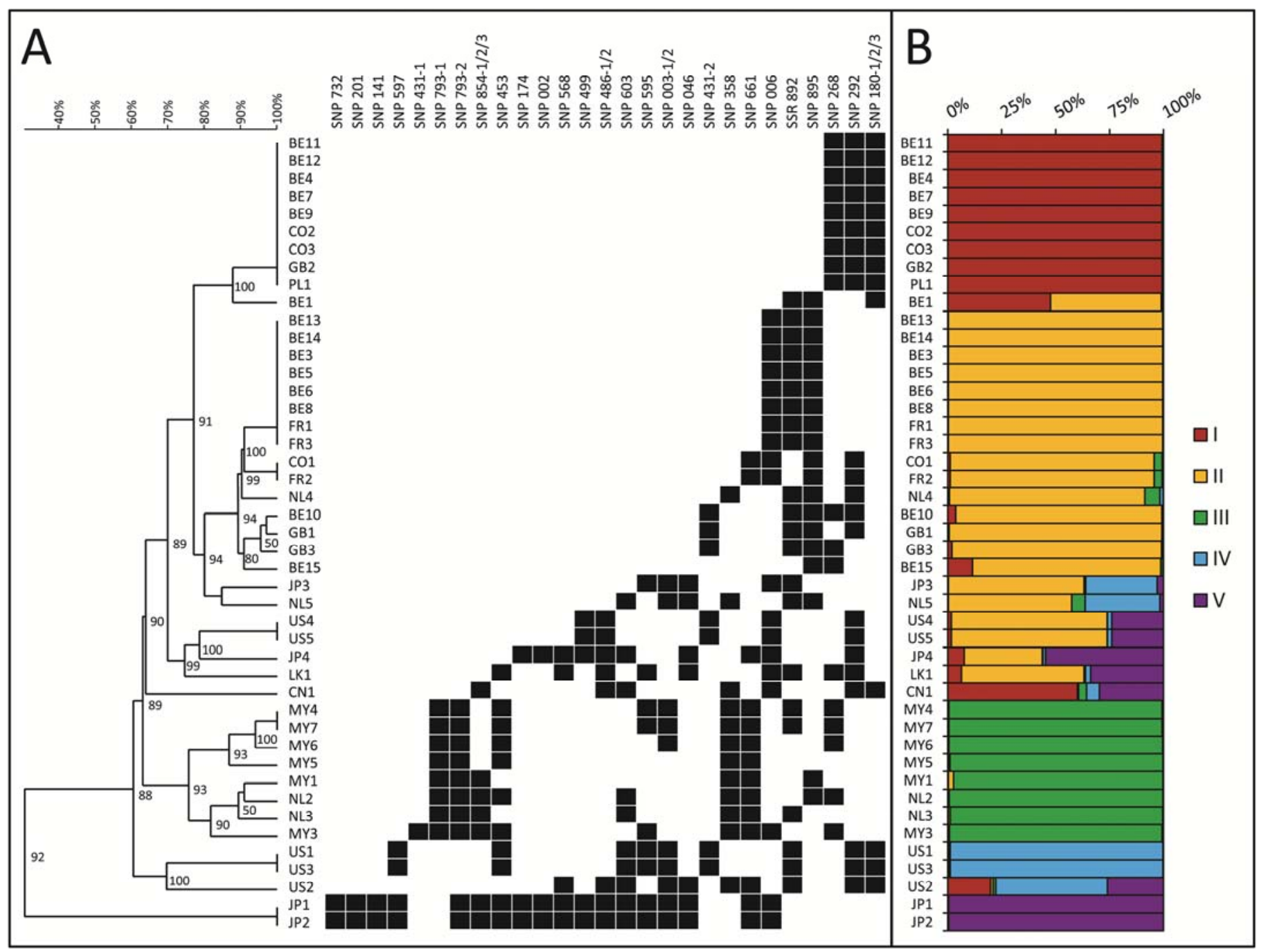

Fig. 1. A, Unweighted pair-group method with arithmetic averages dendrogram of genetic relationships among 45 isolates of Puccinia horiana based on the simple matching similarity coefficients obtained using 32 single-nucleotide polymorphisms (SNPs) and one simple-sequence repeat. Numbers within the tree indicate the cophenetic correlation coefficients for the cluster nodes. Per isolate, the allele for every SNP is presented as described in Table 2. SNPs are sorted right to left based on their presence in the genotypes as sorted from top to bottom. Redundant SNPs in a single fragment are merged and labeled accordingly. B, Mean probability of assignment of each isolate to each of the populations I to $\mathrm{V}$ as determined over 20 parallel Markov chains with STRUCTURE software for K $=5$ is presented. Isolates from the Netherlands had an increased probability of recombination because they were resampled from a mixed culture at a biosecurity facility. This mixed culture included infected material from custom interceptions. 
was determined computationally using an in-house generated routine.

For the isolates with pathotype data, a cluster analysis based on the binary interaction phenotype profiles was performed. Calculation of similarity matrices, cluster analysis, and cophenetic correlation coefficients was conducted as for the genotype data. The correlation between clustering based on genotypes and clustering based on pathotypes was assessed by a Mantel test with 50,000 random iterations using the Mantel Nonparametric Test Calculator 2.0 (34).

\section{RESULTS}

CRoPS analysis and SNP mining. In total, 308,410 highquality reads with an average read length of 144.6 bp were obtained in the CRoPS analysis of eight isolates. Of these, 229,126 could be used in alignments for the de novo assembly of 16,196 contigs with an average read depth per position of 14.2. In total, 77,304 singleton reads and 1,980 chloroplast and mitochondrial reads were not used in contig assembly. In 184 of the 16,196 contigs $(1.1 \%)$ corresponding to $>2.34 \times 10^{6} \mathrm{bp}$, at least one SNP could be found resulting in a SNP frequency of $0.01 \%$. There were 38 alignments with $>10$ reads from at least four different isolates and with a length of at least $100 \mathrm{bp}$. Many of these alignments showed repetitive sequences and were AT rich, complicating primer development. In such cases, multiple primer pairs were tested. Even then, no amplicon could be obtained for six contigs, even in a $\mathrm{T}_{\text {an }}$ gradient PCR of 45 to $60^{\circ} \mathrm{C}$. For another seven contigs, amplicons of the expected size were generated but the putative SNP could not be confirmed by Sanger sequencing. For the remaining 25 contigs, the amplicons had an average length of $172 \mathrm{bp}$ representing 4,300 bp. Eight of these $P$. horiana contigs showed similarity with DNA regions on eight supercontigs of $P$. graminis, $P$. triticina, or $P$. striiformis when a BLASTn search was performed. Although this analysis does not allow determination of the particular chromosomal location of each $P$. horiana marker, we can assume that the markers used here were not closely linked among themselves. A BLASTx search revealed significant homologies with $P$. graminis sequences for five of the $P$. horiana contigs that were identified by the BLASTn search and for three additional contigs, also located on separate $P$. graminis supercontigs. Except for fragment SNP 431, which showed homology with a Cofilin gene, all homologies identified were with hypothetical proteins with unknown function.

Within these 25 PCR fragments, 33 polymorphisms were detected (Table 2). One polymorphism was an SSR (SSR 892) consisting of either five or six "AAC" repeats. The remaining 32 polymorphisms were SNPs, which were present in binary form for all isolates. From the 33 polymorphisms, 24 (23 SNPs and one SSR) were nonredundant (Fig. 1A). In 20 fragments, a single SNP was found; four fragments (CRoPS numbers 003, 431, 486, and 793) contained two SNPs; and two fragments (CRoPS numbers 180 and 854) contained three SNPs (Table 2). The different SNPs within a single fragment were linked and their combined profile also showed a binary format, except for the SNPs in fragments 793 and 431. Also, the SNPs in fragments 141, 201, and 732 and those in fragments 002 and 174 showed identical patterns in all 45 isolates (Fig. 1A). Of the 33 polymorphisms, 31 SNPs were predicted by the CRoPS analysis while two new SNPs were identified (SNP 180-3 and SNP 431-1) in 45 isolates. This would result in a frequency of one SNP in $100 \mathrm{~kb}$ per isolate $(2 / 4,300$ per 45 isolates).

Genotyping and marker recombination. All isolates included in the genotyping were homozygous for the polymorphisms we determined. Within the 45 isolates included in the study, a total of 25 multilocus genotypes could be found based on the differential SNP patterns (Fig. 1A). Seven multilocus genotypes are represented by more than one isolate. These seven genotypes represent
27 isolates, the majority of which can be found in two groups of isolates with nine (BE4, BE7, BE9, BE11, BE12, CO2, CO3, GB2, and PL1 = population I) and eight (BE3, BE5, BE6, BE8, $\mathrm{BE} 13, \mathrm{BE} 14, \mathrm{FR} 3$, and FR1 = isolates with identical genotype in population II) isolates, respectively (Fig. 1A). Other isolates with identical genotypes grouped in twos: isolates CO1 and FR2, US4 and US5, MY4 and MY7, US1 and US3, and JP1 and JP2. The remaining 18 isolates all had unique genotypes. In most cases, isolates with identical genotypes were sampled in the same geographic region but in different growing seasons. Examples are BE4 (2005) and BE12 (2007), BE3 (2003) and BE6 (2008), and US1 (2008) and US3 (2010).

The SNP profiles of 20 isolates represent potential recombinations of other profiles (Fig. 1A; Table 3). For example, BE1 shares the polymorphisms SNP 180 1-3 and SNP 006 with the isolates of population I. It shares polymorphisms SSR 892, SNP 268, SNP 895, and SNP 292 with the main genotype of population II and also contains all the alleles that are shared by these potential parental genotypes. Most recombinant genotypes can be explained by several potential combinations of parental genotypes, with a maximum of 31 different combinations for the genotype of isolate BE15 (Table 3, bottom line). However, when several combinations are possible, one or a few related genotypes are usually repeatedly identified as one of the potential parents, suggesting that these genotypes or one closely related to them are likely to be involved in the ancestry of the recombinant genotype. This is illustrated in isolate GB1, for which genotype BE10 is one of the parental candidates in 15 of the 30 possible combinations. Similarly, the JP1/JP2 genotype is likely ancestral to the geographically related isolates JP3 and JP4. Within the Malaysian genotypes, several parent-recombinant possibilities can also be observed (Table 3). However, the parental and recombinant isolates are not always characterized by geographic closeness, as illustrated by genotype BE13, which has markers from the Chinese genotype, and by the genotype of the Dutch isolate NL2, which is related to the genotype of the Malaysian isolate MY3. For five genotypes, represented by seven isolates (CN1, MY3, US1/US3, US2, and JP1/JP2), no potential ancestral genotype could be identified in the dataset even though they are important parental genotypes themselves.

SNP data analysis. The dendrogram showing the evolutionary relations of the isolates based on the simple matching similarity coefficients and the UPGMA method is shown in Figure 1A. Cophenetic correlation coefficients of $>85 \%$ were observed, indicating that the dendrogram is a good representation of the similarity matrix. Similar clustering was obtained using the neighborjoining and maximum-likelihood methods.

There is a clear division between the Japanese isolates JP1 and JP2 and the remaining isolates in our collection at a genetic similarity of $30 \%$. At an arbitrary threshold of $65 \%$ similarity, three main clusters can be distinguished among these 43 other isolates. The largest cluster represents 31 isolates originating in Europe, the United States, Colombia, Japan, and Sri Lanka. The second cluster represents eight isolates originating in Malaysia and the Netherlands, while the last cluster represents three isolates originating in the United States. Isolate CN1 was not assigned to a cluster at the $65 \%$ similarity level.

The Bayesian analysis of population structure resulted in optimal $\mathrm{K}$ values of 5 or 7 (Supplementary Figure 1). For $\mathrm{K}=5$, the 20 parallel Markov chains resulted in identical structuring of isolates (Fig. 1B). Assuming an arbitrary threshold of $q=0.85$ for the assignment of an isolate to a population, 36 of the 45 isolates could be assigned to one population. The genotypes of the nine remaining isolates could not be assigned clearly as the result of admixture (discussed below). For $\mathrm{K}=7$, three possible splitting solutions were found, although the major groups that were determined for $\mathrm{K}=5$ were maintained (Supplementary Figure 2), indicating that the $\mathrm{K}=5$ solution is the most consistent one. This 
solution largely agreed with the UPGMA clustering represented in the dendrogram (Fig. 1A).

The resulting five populations contain one to nine genotypes each (Fig. 1B). Three of these populations (I, IV, and V) correspond to isolates with identical genotypes described above (Fig. 1A). All isolates in the two remaining populations II (15 isolates, seven genotypes) and III (eight isolates, seven genotypes) share one and four rare alleles, respectively. Most populations are dominated by isolates from the same geographic origin. Populations I and II predominantly contain isolates from Europe. Isolates in population III mostly originate in Malaysia, isolates in population IV originate from the United States, and isolates in population V originate in Japan. However, despite this general correlation between geographic origin and phylogenetic clustering, some inconsistencies are also observed. In populations I and II, two and one Colombian isolates, respectively, with genotypes identical to European isolates can be found. Similarly, two isolates from the Netherlands group with the Malaysian isolates in population III. Although the remaining isolates group with particular genotypes in the dendrogram, their genotype profiles are the result of admixture between genotypes of different populations. For most genotypes that show admixture, correspondence is observed between the admixed populations and the populations to which the candidate parental genotypes from the recombination analysis belong (e.g., for isolates BE1, NL5, JP4, and LK1). However, for some isolates that show admixture, no candidate parental profiles are present (e.g., US2 and CN1).

Pathotype correlation analysis. A cluster analysis based on the pathotype profiles of a subset of 26 isolates is shown in Figure 2. The diversity in these phenotypic profiles is larger than in the genotypic profiles, because each isolate had a unique "pathotype pattern". The correlation between the genotypic distance matrix and the phenotypic distance matrix was not significant at the 5\% threshold when tested using a Mantel test but had a low $P$ value $\left(P=0.055 ; R^{2}=0.062\right)$. Isolates from populations I, II, IV, and V show related pathotype profiles, with some subclustering at the population level, except for isolate BE3 and isolates which are the result of admixture. In contrast, the isolates from population III, including isolates from Malaysia (MY1) and the Netherlands (NL2 and NL3), have completely different pathotype profiles. Also, isolates NL1 and NL6, for which no genotype profile could be determined, can be found in this second pathotype cluster. Marker SNP793-1 is uniquely associated with this separate pathotype cluster.

\section{DISCUSSION}

Determination of the genetic diversity of obligate pathogens is very difficult because the development of molecular markers requires the availability of pure pathogen DNA, which is difficult to obtain in sufficient quantities due to contaminating DNA from the host or from contaminating microorganisms. For example, AFLP profiles obtained in this study using $P$. horiana pustule DNA could not be resolved due to the bands resulting from variable amounts of contaminating plant DNA (data not shown). Even if a sufficient amount of pure DNA could be obtained for whole-genome sequencing and SNP mining, the cost of de novo sequencing of several isolates at the time this study was initiated prevented such a strategy. We partly resolved these contamination issues by obtaining pure DNA from a limited number of isolates

TABLE 3. Potential recombination events among the genotypes in our collection ${ }^{\mathrm{a}}$

\begin{tabular}{|c|c|c|c|c|c|c|c|c|c|c|c|c|c|c|c|c|c|c|c|c|c|c|c|c|c|}
\hline \multirow[b]{3}{*}{ Parental $^{\text {b }}$} & \multicolumn{25}{|c|}{ Potential recombinant genotypes } \\
\hline & \multirow{2}{*}{$\begin{array}{c}\text { Pop. I } \\
0 \\
\stackrel{0}{\oplus}\end{array}$} & \multirow[b]{2}{*}{ 표 } & \multicolumn{7}{|c|}{ Pop. II } & \multirow[b]{2}{*}{$\hat{\Omega}$} & \multirow[b]{2}{*}{ 光 } & \multirow[b]{2}{*}{ 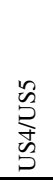 } & \multirow[b]{2}{*}{ 吉 } & \multirow[b]{2}{*}{ 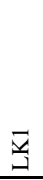 } & \multirow[b]{2}{*}{$\bar{Z}$} & \multicolumn{7}{|c|}{ Pop. III } & \multirow{2}{*}{\begin{tabular}{l} 
Pop. IV \\
\multirow{2}{\Xi}{} \\
$\stackrel{\Xi}{\Omega}$
\end{tabular}} & \multirow[b]{2}{*}{ 气ี } & \multirow{2}{*}{$\begin{array}{l}\text { Pop. V } \\
\text { ह }\end{array}$} \\
\hline & & & 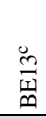 & $\frac{\substack{1 \\
0}}{0}$ & 芝 & 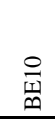 & $\overline{0}$ & 节 & $\frac{n}{n}$ & & & & & & & 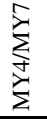 & $\stackrel{0}{\Sigma}$ & $\stackrel{n}{\Sigma}$ & $\bar{\Sigma}$ & 之 & $\hat{z}$ & $\stackrel{\overbrace{}}{\Sigma}$ & & & \\
\hline $\mathrm{BE} 11^{\mathrm{c}}$ & $\ldots$ & 2 & 7 & $\ldots$ & 1 & 2 & $\ldots$ & $\ldots$ & 5 & $\ldots$ & $\ldots$ & $\ldots$ & 1 & $\ldots$ & $\ldots$ & $\ldots$ & 1 & $\ldots$ & $\ldots$ & $\ldots$ & $\ldots$ & $\ldots$ & $\ldots$ & $\ldots$ & $\ldots$ \\
\hline BE1 & $\ldots$ & $\ldots$ & $\ldots$ & 1 & $\ldots$ & $\ldots$ & 2 & 1 & 3 & 1 & $\ldots$ & $\ldots$ & $\ldots$ & $\ldots$ & $\ldots$ & $\ldots$ & $\ldots$ & 2 & 2 & $\ldots$ & $\ldots$ & $\ldots$ & $\ldots$ & $\ldots$ & $\ldots$ \\
\hline $\mathrm{BE} 13^{\mathrm{c}}$ & $\ldots$ & 3 & $\ldots$ & 1 & 1 & $\ldots$ & 2 & 1 & 3 & 1 & 1 & $\ldots$ & $\ldots$ & $\ldots$ & $\ldots$ & $\ldots$ & $\ldots$ & 1 & 1 & $\ldots$ & $\ldots$ & $\ldots$ & $\ldots$ & $\ldots$ & $\ldots$ \\
\hline $\mathrm{CO} 1 / \mathrm{FR} 2$ & $\ldots$ & $\ldots$ & 4 & $\ldots$ & 1 & 1 & 3 & $\ldots$ & 1 & $\ldots$ & $\ldots$ & $\ldots$ & 1 & $\ldots$ & $\ldots$ & $\ldots$ & 1 & 2 & 2 & $\ldots$ & $\ldots$ & $\ldots$ & $\ldots$ & $\ldots$ & $\ldots$ \\
\hline NL4 & $\ldots$ & $\ldots$ & 2 & 2 & $\ldots$ & 1 & 4 & $\ldots$ & $\ldots$ & 1 & 1 & $\ldots$ & 1 & $\ldots$ & $\ldots$ & $\ldots$ & $\ldots$ & 2 & 2 & $\ldots$ & $\ldots$ & $\ldots$ & $\ldots$ & $\ldots$ & $\ldots$ \\
\hline BE10 & 1 & $\ldots$ & 2 & 2 & 6 & $\ldots$ & 15 & 13 & 6 & 1 & $\ldots$ & 2 & 1 & 1 & $\ldots$ & $\ldots$ & $\ldots$ & $\ldots$ & 2 & $\ldots$ & $\ldots$ & $\ldots$ & $\ldots$ & $\cdots$ & $\ldots$ \\
\hline GB1 & $\ldots$ & $\ldots$ & 3 & 3 & 10 & 8 & $\ldots$ & 5 & 3 & 1 & $\ldots$ & 2 & 1 & $\ldots$ & $\ldots$ & $\ldots$ & $\ldots$ & 2 & $\ldots$ & $\ldots$ & $\ldots$ & $\ldots$ & $\ldots$ & $\ldots$ & $\ldots$ \\
\hline GB3 & 1 & 2 & 5 & 1 & 2 & 10 & 7 & $\ldots$ & 10 & 1 & 1 & 1 & $\ldots$ & $\ldots$ & $\ldots$ & $\ldots$ & $\ldots$ & $\ldots$ & $\ldots$ & $\ldots$ & $\ldots$ & $\ldots$ & $\ldots$ & $\ldots$ & $\ldots$ \\
\hline BE15 & 3 & 2 & 1 & 1 & 1 & 2 & 1 & 3 & $\ldots$ & $\ldots$ & 1 & $\ldots$ & $\ldots$ & $\ldots$ & $\ldots$ & $\ldots$ & 1 & $\ldots$ & 1 & $\ldots$ & $\ldots$ & $\ldots$ & $\ldots$ & $\ldots$ & $\ldots$ \\
\hline JP3 & $\ldots$ & $\ldots$ & 9 & $\ldots$ & $\ldots$ & $\ldots$ & 1 & 1 & 1 & $\ldots$ & 1 & $\ldots$ & $\ldots$ & $\ldots$ & $\ldots$ & 2 & 1 & 1 & 1 & $\ldots$ & 1 & $\ldots$ & $\ldots$ & $\ldots$ & $\ldots$ \\
\hline NL5 & $\ldots$ & 1 & 2 & $\ldots$ & 5 & $\ldots$ & 2 & 1 & 1 & 1 & $\ldots$ & $\ldots$ & $\ldots$ & $\ldots$ & $\ldots$ & 1 & 1 & 1 & 1 & 1 & 1 & $\ldots$ & $\ldots$ & $\ldots$ & $\ldots$ \\
\hline US4/US5 & $\ldots$ & $\ldots$ & 2 & 2 & 1 & 1 & 5 & $\ldots$ & 1 & $\ldots$ & $\ldots$ & $\ldots$ & 1 & $\ldots$ & $\ldots$ & $\cdots$ & 1 & 3 & 1 & $\cdots$ & $\ldots$ & $\ldots$ & $\ldots$ & $\ldots$ & $\ldots$ \\
\hline JP4 & $\ldots$ & $\ldots$ & 2 & 8 & $\ldots$ & 1 & 2 & $\ldots$ & 1 & $\ldots$ & $\ldots$ & 3 & $\ldots$ & $\ldots$ & $\ldots$ & $\ldots$ & 1 & 2 & $\ldots$ & $\ldots$ & $\ldots$ & $\ldots$ & $\ldots$ & $\ldots$ & $\ldots$ \\
\hline LK1 & $\ldots$ & $\ldots$ & 2 & 1 & 1 & 2 & $\ldots$ & $\ldots$ & 1 & 1 & $\ldots$ & $\ldots$ & $\ldots$ & $\ldots$ & $\ldots$ & 1 & $\ldots$ & 1 & $\ldots$ & $\ldots$ & $\ldots$ & $\ldots$ & $\ldots$ & $\ldots$ & $\ldots$ \\
\hline $\mathrm{CN} 1$ & 3 & 1 & 1 & $\ldots$ & 3 & 1 & 2 & $\ldots$ & 1 & $\ldots$ & $\ldots$ & $\ldots$ & $\ldots$ & $\ldots$ & $\ldots$ & $\ldots$ & 1 & 2 & $\ldots$ & $\ldots$ & 1 & $\ldots$ & $\ldots$ & $\ldots$ & $\ldots$ \\
\hline MY4/MY7 & $\ldots$ & $\ldots$ & $\ldots$ & $\ldots$ & 1 & 1 & $\ldots$ & 2 & $\ldots$ & $\ldots$ & $\ldots$ & $\ldots$ & $\ldots$ & $\ldots$ & $\ldots$ & $\ldots$ & 9 & 5 & $\ldots$ & $\ldots$ & 1 & $\ldots$ & $\ldots$ & $\ldots$ & $\ldots$ \\
\hline MY6 & $\ldots$ & $\ldots$ & $\ldots$ & $\ldots$ & 1 & 1 & $\ldots$ & 2 & 5 & $\ldots$ & $\ldots$ & $\ldots$ & $\ldots$ & $\ldots$ & $\ldots$ & 3 & $\ldots$ & 10 & $\ldots$ & $\ldots$ & $\ldots$ & $\ldots$ & $\ldots$ & $\ldots$ & $\ldots$ \\
\hline MY5 & $\ldots$ & $\ldots$ & $\ldots$ & $\ldots$ & 2 & $\ldots$ & 1 & 1 & 2 & $\ldots$ & $\ldots$ & $\ldots$ & $\ldots$ & $\ldots$ & $\ldots$ & $\ldots$ & 1 & $\ldots$ & $\ldots$ & $\ldots$ & $\ldots$ & $\ldots$ & $\ldots$ & $\ldots$ & $\ldots$ \\
\hline MY1 & $\ldots$ & 1 & 2 & 3 & 4 & $\ldots$ & 2 & 1 & 4 & $\ldots$ & $\ldots$ & $\ldots$ & $\ldots$ & $\ldots$ & $\ldots$ & $\ldots$ & 1 & 4 & $\ldots$ & $\ldots$ & 2 & $\ldots$ & $\ldots$ & $\ldots$ & $\ldots$ \\
\hline NL2 & $\ldots$ & $\ldots$ & 1 & 1 & 1 & 1 & $\ldots$ & 2 & 8 & $\ldots$ & 1 & $\ldots$ & $\ldots$ & $\ldots$ & $\ldots$ & 1 & 2 & 2 & 7 & $\ldots$ & 2 & $\ldots$ & $\ldots$ & $\ldots$ & $\ldots$ \\
\hline NL3 & $\ldots$ & $\ldots$ & $\ldots$ & $\ldots$ & 2 & $\ldots$ & 1 & 1 & $\ldots$ & $\ldots$ & $\ldots$ & $\ldots$ & $\ldots$ & $\ldots$ & $\ldots$ & $\ldots$ & $\ldots$ & 1 & 2 & $\ldots$ & $\ldots$ & $\ldots$ & $\ldots$ & $\ldots$ & $\ldots$ \\
\hline MY3 & $\ldots$ & $\ldots$ & 2 & 1 & 1 & 1 & $\ldots$ & 2 & 4 & $\ldots$ & $\ldots$ & $\ldots$ & $\ldots$ & $\ldots$ & $\ldots$ & 3 & 2 & 5 & 4 & 1 & 2 & $\ldots$ & $\ldots$ & $\ldots$ & $\ldots$ \\
\hline US1/US3 & 1 & 3 & $\ldots$ & $\ldots$ & 1 & 2 & 7 & 1 & $\ldots$ & $\ldots$ & $\ldots$ & $\ldots$ & $\ldots$ & $\ldots$ & $\ldots$ & 2 & $\ldots$ & 1 & $\ldots$ & $\ldots$ & 1 & $\ldots$ & $\ldots$ & $\ldots$ & $\ldots$ \\
\hline US2 & 1 & 3 & $\ldots$ & $\ldots$ & 5 & 1 & 2 & $\ldots$ & $\ldots$ & $\ldots$ & 3 & $\ldots$ & $\ldots$ & $\ldots$ & $\ldots$ & 1 & 1 & 1 & $\ldots$ & $\ldots$ & 3 & $\ldots$ & $\ldots$ & $\ldots$ & $\ldots$ \\
\hline JP1/JP2 & $\ldots$ & $\ldots$ & 5 & 3 & $\ldots$ & $\ldots$ & 1 & 1 & 2 & 6 & 1 & 2 & 6 & 1 & & $\ldots$ & $\ldots$ & $\ldots$ & $\ldots$ & $\ldots$ & $\ldots$ & $\ldots$ & $\ldots$ & $\ldots$ & $\ldots$ \\
\hline Total $^{\mathrm{d}}$ & 5 & 9 & 26 & 15 & 25 & 18 & 30 & 19 & 31 & 7 & 5 & 5 & 6 & 1 & 0 & 7 & 12 & 24 & 13 & 1 & 7 & 0 & 0 & 0 & 0 \\
\hline
\end{tabular}

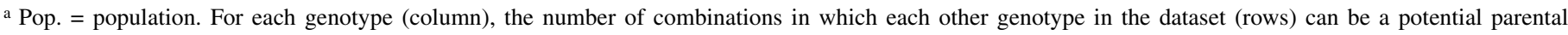
genotype is listed at the row-by-column intersection. A relatively high number in a column indicates an increased chance that the genotype in the corresponding row is a possible ancestor of the recombinant genotype in the corresponding column. The largest value is marked with a dark shading and the second-largest value (other than 1) is marked with a lighter shading.

b Potential parental genotypes.

c More than three isolates belong to this genotype.

$\mathrm{d}$ Total number of potential recombination events. 
via a basidiospore harvesting technique. Even then, there still was some contamination by other microorganisms but the sequencing and alignment of the contigs of resulting AFLP fragments using the CRoPS technique (48) largely eliminated non- $P$. horiana sequences in our analysis (data not shown). Candidate SNPs were identified and developed into markers that could subsequently be

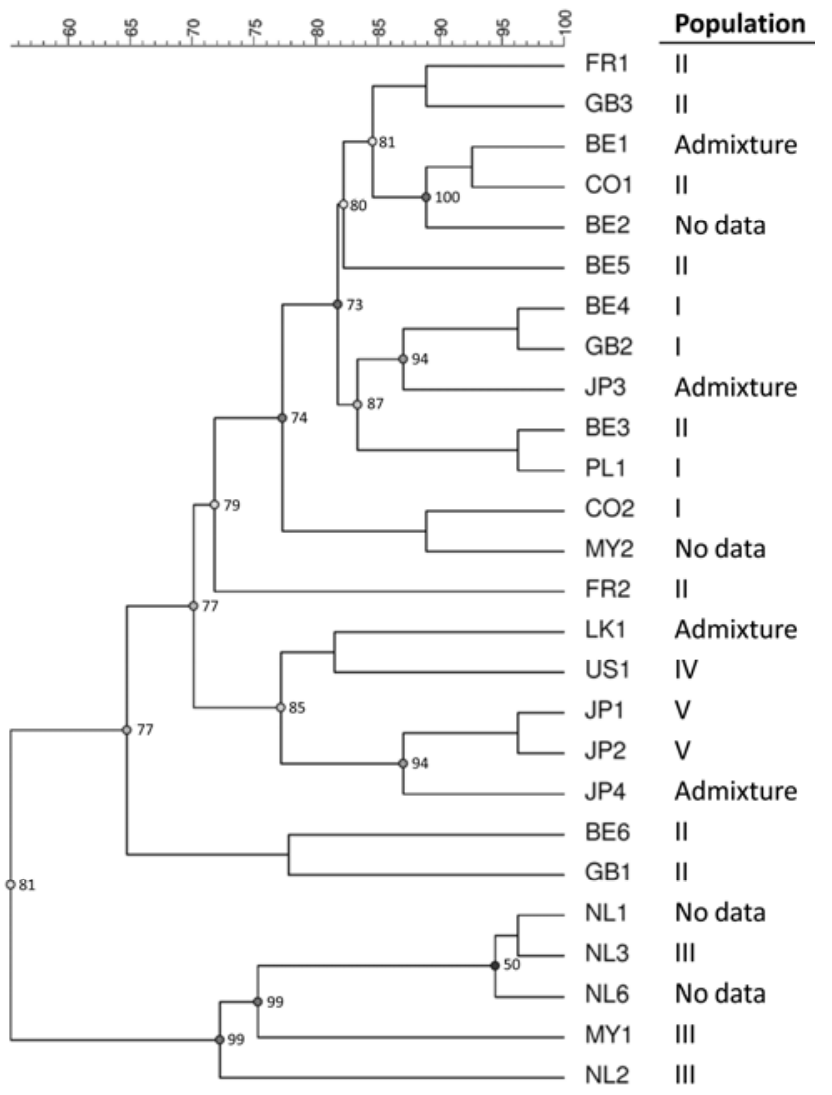

Fig. 2. Unweighted pair-group method with arithmetic averages dendrogram of relationships among 26 isolates of Puccinia horiana based on the simple matching similarity coefficients obtained using the interaction phenotype profiles on a set of 36 cultivars, as described by De Backer et al. (10). The population (or admixture) of the isolates is listed next to the isolate code. Numbers within the tree indicate the cophenetic correlation coefficients for the cluster nodes. tested on non-pure DNA of a larger collection of isolates using $P$. horiana-specific PCR primers. In combination with a wholegenome amplification step, the specific SNP markers could be screened using only a few pustules and even in the presence of contaminating plant DNA. Therefore, the primer pairs presented here allow direct screening of samples obtained during quarantine screening, without the need for a labor-intensive, time-consuming, and costly propagation of the pathogen at an appropriate biosafety facility. Although a whole-genome amplification step can create an amplification bias (42), we did not observe any mutations due to this step. The use of a whole-genome amplification also resulted in a good representation of the original genome in the rust pathogen P. striiformis f. sp. tritici (53).

Approximately $0.01 \%$ of the $2.35 \times 10^{6}$ nucleotide positions that were analyzed using CRoPS were polymorphic. This indicates that the SNP frequency of $P$. horiana is extremely low compared with other fungi; rates of $1.20 \%$ in Candida albicans (19), $1.71 \%$ in Tricholoma matsutake (56), $1.35 \%$ in Aspergillus fumigatus (2), $0.25 \%$ in Pandora neoaphidis (20), and $0.53 \%$ in the rust Puccinia striiformis f. sp. tritici (8) have been described. The low SNP frequencies in $P$. horiana can be due to the relatively restricted and patchy distribution of the chrysanthemum host, resulting in a smaller likelihood of mutants to find a host and remain in the population. On the other hand, the pathogen may have experienced (recent) bottlenecks due to the strict quarantine measures in most parts of the world. As expected, there are strong indications that the SNP markers are stable: the European isolates with identical genotypes were collected between 2003 and 2007 and, except for marker SNP431/1, all markers were found in at least two isolates, suggesting that they were not caused by PCR artifacts. For $11(8+3)$ of the 25 contigs, similarities with genomic or protein sequences of $P$. graminis f. sp. tritici, $P$. triticina, and $P$. striiformis f. sp. tritici $(7,12)$ were identified. Similarity to sequences on different supercontigs supports the assumption of a random distribution of the marker loci developed here in the $P$. horiana genome. Only in one case was similarity observed to a protein of known function.

Notably, all SNPs that were identified are homozygous. This is in contrast with the high levels of heterozygosity observed in other rusts (33). However, homozygosity of the markers can be explained by the exceptional microcyclic life cycle of $P$. horiana, in which the basidia produce only two (instead of four) basidiospores, each of which receives two nuclei (instead of one) $(30,31)$ (Fig. 3A). These nuclei are derived from the second meiotic division and, therefore, are identical. The hyphae and pustules

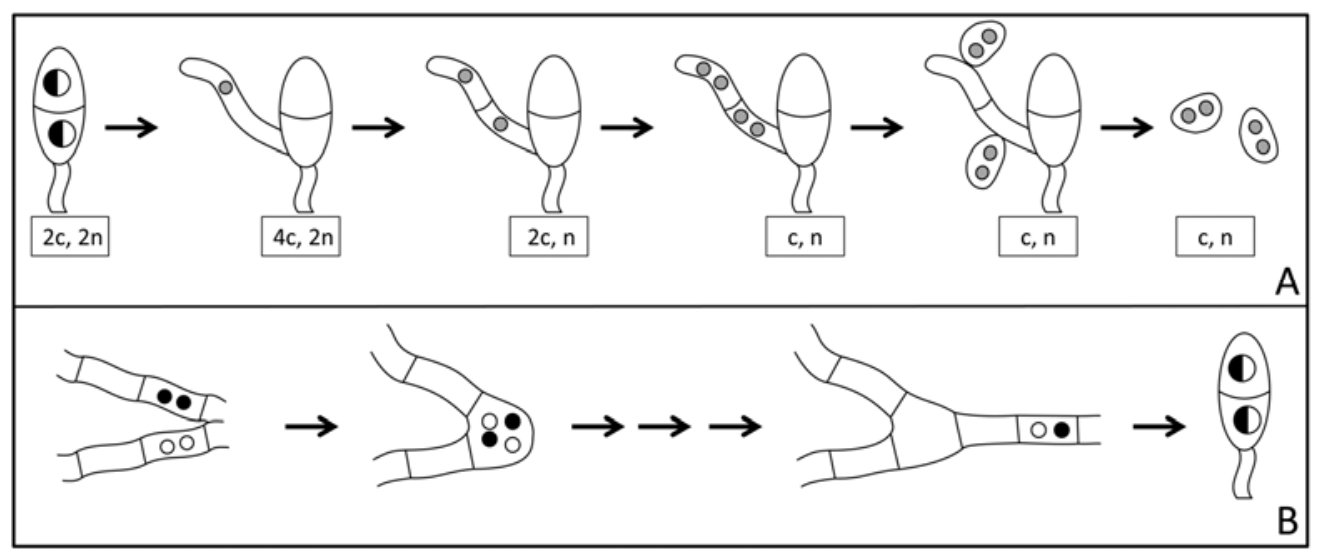

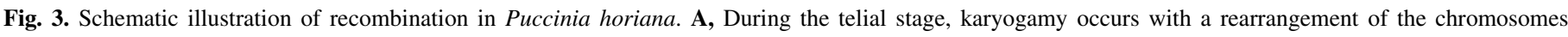

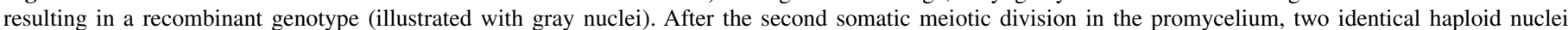

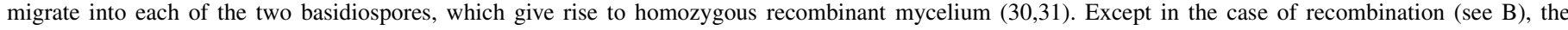

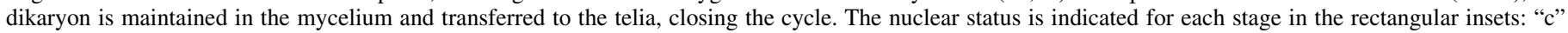

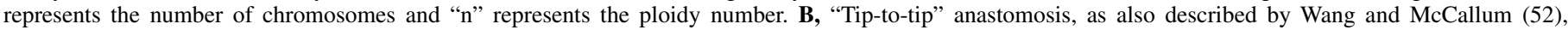

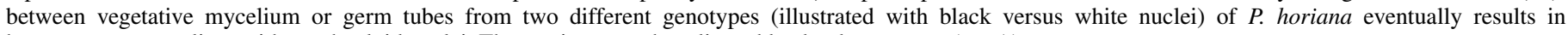
heterozygous mycelium with two haploid nuclei. These migrate to the telia and lead to karyogamy (see A). 
that are derived from each basidiospore will all contain these identical nuclei; hence the homozygous nature of the markers in single pustule isolates. A heterozygous state of a marker can only occur in case of a mitotic mutation or after anastomosis with another genotype. However, even in these rare events, the following nuclear cycle will restore the homozygous state of each marker in the basidiospores.

Isolates that appear to be clonal based on the obtained genotype profiles were observed within the geographic regions where the pathogen is considered endemic, such as in Europe, Japan, and Malaysia. This is expected, because these isolates represent relatively recent local dispersal. For example, the five Belgian isolates from the area of Mechelen mostly have identical genotypes and all group together in population II. The isolates with identical genotypes from populations I and II were also found in France, Poland, and the United Kingdom, indicating that longer distance spread within Europe also occurred, either via commercial trade of infected plants or, less likely, via very longdistance spore dispersal $(5,38)$. A perfect match of the two genotypes of the Colombian isolates with genotypes co-occurring in Europe strongly supports repeated international long-distance dispersal, presumably via commercial trade of infected plants. In case of $\mathrm{CO} 2$ and $\mathrm{CO} 3$, which have a genotype identical to that of the isolates from population I that were sampled in at least three European countries, the likely direction of the transfer is from Europe to Colombia. For CO1, whose genotype was also found in a single French isolate, it is not possible to determine the direction of the transfer. The Dutch isolates NL2 and NL3 may also be examples of recent international transfer: although their genotypes do not perfectly match with any other genotype, their profiles cluster with isolates from Malaysia. The NL3 isolate is possibly an import interception (Table 1) and may not have spread in the Netherlands.

Although the presence of isolates with identical genotypes within most regions was clearly demonstrated, the genotypic diversity in each of the regions was larger than expected. In Europe, there were 12 genotypes among 25 isolates; in Malaysia, there were 5 genotypes among the 6 isolates; and, in Japan, there were 3 genotypes among the 4 isolates. The marker profiles within a geographic region did not follow a pattern of stepwise accumulation of mutations, typical for an organism with a presumed asexual cycle. Particularly striking was that certain genotypes appear to have recombinant patterns of SNPs found in isolates that originate in different geographic regions. This is obvious for the Japanese isolates, which serve as a donor for markers present in isolates originating in Europe, Colombia, Sri Lanka, and the United States (Table 3). These observations indicate recombination and transfer of genotypes and demonstrate that a parasexual cycle is present, disproving the presumed strict asexual nature of this organism. The recombination in $P$. horiana may be explained by heterokaryosis after anastomosis of germ tubes or vegetative mycelium, resulting in heterozygous vegetative mycelium (Fig. 3B). After somatic meiotic division in the telial stage, homozygous recombinant genotypes can be expected based on the microscopic observations of somatic meiotic nuclear divisions in P. horiana (30,31) (Fig. 3A), as we indeed observed in our results. Germ tube anastomosis has recently been described for uredinial germtubes in the rust species $P$. triticina (52) and Phakopsora pachyrhizi (50). Anastomosis after basidial infection of a microcyclic rust has been suggested by Ono (41). Isolate BE1 is most likely a local recombinant of the two main genotypes in Belgium (population I and the main genotype of population II). In the other geographic regions, for which fewer isolates were collected, there are also clear indications of recombination. In fact, nearly all SNPs identified are found in various combinations, which is in disagreement with simple asexual propagation in clonal lineages. However, as in most areas where the sampling is sparse, we can expect that important genotypes are missing for those regions. Because the dominant genotypes are unknown in most regions other than Europe, there is also uncertainty as to the exact identity of the parents. Standard parental analysis software such as Cervus (27), Parente (9), Famoz (21), Kinship (22), Kingroup (32), and Colony (26) could not be applied for parental analysis because they are limited to diploid or haplo-diploid systems. Consequently, a simple in-house routine was generated for recombination analysis.

The U.S. isolates are unique in that, until recently, the pathogen was not considered endemic in this country (46). The five U.S. isolates include three genotypes, none of which are directly related to each other as recombinants (Table 3). This indicates that at least three separate introductions into the United States took place. Isolates US4 and US5 have the same multilocus genotype, and so do isolates US1 and US3. They were sampled in different states and, in case of US1 and US3, also 3 years apart; therefore, survival and spread of these isolates within the United States is possible, indicating that Puccinia horiana may now be endemic in the United States. This is supported by observations of overwintering of $P$. horiana outdoors on infected plants in Pennsylvania $(29,40)$. Alternatively, repeated introduction of isolates of these two genotypes may have occurred. Collection of trace-back information on the source of imported plants as well as genotyping of more U.S. isolates and isolates from the possible geographic origins of imported plant material will provide further evidence for one of these hypotheses. Four of five U.S. isolates also share the rare allele SNP431/2, which probably resulted from a historic recombination with the as-yet-unidentified parental genotype that also donated this marker to isolates BE10, GB1, and GB3. Isolates with parental genotypes to isolates CN1, MY3 (population III), US1/US3 (population IV), US2 (admixture), and JP1/2 (population V) were not identified (Table 3). We hypothesize that these genotypes are potentially ancestral and donors of specific markers in recombination events.

The diversity based on the pathotype data was significantly higher than the genotypic diversity. This larger diversity can be explained by the complex pattern resulting from the interaction between at least seven resistance genes in Chrysanthemum with corresponding avirulence genes in the pathogen (10). Even among isolates with the same genotype, clear differences in pathotypes were observed (e.g., BE3 versus BE6). This higher diversity can be explained by epigenetic changes in disease resistance, which are more flexible than sequence mutations (47), or by higher selection pressure on avirulence genes due to exposure of the pathogen to cultivars with specific resistance genes. The correlation between the clusters of the pathotype- and genotype-based dendrograms was not significant but the $P$ value was low $(P=$ $0.055)$, indicating some relation between pathotypes and genotypes. The isolates of population III are the most virulent ones identified thus far. They probably lack several avirulence genes, including one that corresponds to a frequently used resistance gene (10). This resulted in a clearly differentiated pathotype cluster. The number of recombination events with exotic isolates in Malaysia seems to have been limited, resulting in a clear genotype cluster for these isolates. There is currently no information on the location of the avirulence genes or their physical proximity to each other within the genome of $P$. horiana. Avirulence genes in other rust fungi have been identified in clusters as well as individually on different chromosomes $(4,33)$. Their actual position in the $P$. horiana genome will determine the chance for rearrangement during recombination and, therefore, the potential for the creation of new pathotypes. This is especially relevant if the parental isolates each lack important avirulence genes.

Our results demonstrate that recombination occurs on a regular basis in a presumed asexual organism like $P$. horiana, thus increasing the potential formation of genotypes with greater virulence. This may have practical implications when mixed inocu- 
lations with presumed asexual organisms are used as a timesaving strategy in resistance breeding programs. Because this may lead to the undesirable side effect of generating a highly adapted pathogen in the process, such screens should only be performed in strict containment. Given the risk for recombination demonstrated in this work, co-existence of $P$. horiana isolates with different genotypes should be avoided in nurseries. For example, potentially infected planting material from different locations should not be propagated in the same greenhouse. Similarly, outdoor epidemics should be controlled in regions where different pathotypes are present.

The SNP and SSR markers we developed allow for the rapid genotypic characterization of isolates of $P$. horiana. After the development of faster SNP detection methods, such as real-time PCR with high-resolution melt analysis (35) or SNP detection using Luminex technology, these markers will become fast and relatively inexpensive tools to screen many samples. Such tools would be suitable to track and trace isolates, allowing us to address questions relating to transfer and survival of the pathogen or effectiveness of quarantine measures. It would also allow us to identify potential recombinants and monitor populations at a global level. Genotyping of isolates from intercepted import shipments would determine whether or not they belong to a given genotype that is already present in the region of import. Of course, this implies that the endemic population has been characterized, which will provide extra information as to the relative frequencies of the genotypes present. Such genotyping would help evaluate the possible risk of impact of the specific introduction. A first step toward the identification of high-risk genotypes may be the unique marker (SNP793-1) that was identified in this study. However, novel loss of avirulence may also occur in resident genotypes or in exotic genotypes that do not contain the specific marker. Such events would not be detected with association markers. Until the sequence of the specific avirulence genes of $P$. horiana has been determined and used to develop DNAmarkers, associated markers such as SNP793-1 are our best option for fast detection of isolates with a potentially higher pathogenic potential.

\section{ACKNOWLEDGMENTS}

M. De Backer expresses his appreciation to ILVO for his Ph.D. scholarship. We thank M. van Gent-Pelzer (Plant Research International) for the whole-genome amplifications of $P$. horiana DNA; KeyGene for the AFLP and CRoPS analysis; K. van 't Hoenderdal (Dekker Chrysanten), A. Post (Deliflor), B. Brandwagt (Royal Van Zanten), J. Guerrand (BBV), S. McDonough (Fera), A. Wojdyla (INSAD), and W. Janssen (PD) for supplying some of the isolates; Plantum, the Belgian Federal Agency for the Safety of the Food Chain (FAVV) (NRL agreement10ILVOCRAPLANTEN), and the Dutch Ministry of Economic Affairs, Agriculture and Innovation for partial financial support of this project; and D. Ravier for his help in the maintenance of the isolates. Mention of trade names or commercial products in this publication is solely for the purpose of providing specific information and does not imply recommendation or endorsement by the United States Department of Agriculture (USDA). USDA is an equal opportunity provider and employer.

\section{LITERATURE CITED}

1. Alaei, H., De Backer, M., Nuytinck, J., Maes, M., Hofte, M., and Heungens, K. 2009. Phylogenetic relationships of Puccinia horiana and other rust pathogens of Chrysanthemum $\times$ morifolium based on rDNA ITS sequence analysis. Mycol. Res. 113:668-683.

2. Bain, J. M., Tavanti, A., Davidson, A. D., Jacobsen, M. D., Shaw, D., Gow, N. A. R., and Odds, F. C. 2007. Multilocus sequence typing of the pathogenic fungus Aspergillus fumigatus. J. Clin. Microbiol. 45:14691477.

3. Baker, J. J. 1967. Chrysanthemum white rust in England and Wales $1963-$ 66. Plant Pathol. 16:162-166.

4. Bolton, M. D., Kolmer, J. A., and Garvin, D. F. 2008. Wheat leaf rust caused by Puccinia triticina. Mol. Plant Pathol. 9:563-575.
5. Brown, J. K. M., and Hovmoller, M. S. 2002. Aerial dispersal of pathogens on the global and continental scales and its impact on plant disease. Science 297:537-541.

6. Brumfield, R. T., Beerli, P., Nickerson, D. A., and Edwards, S. V. 2003. The utility of single nucleotide polymorphisms in inferences of population history. Trends Ecol. Evol. 18:249-256.

7. Cantu, D., Govindarajulu, M., Kozik, A., Wang, M., Chen, X., Kojima, K. K., Jurka, J., Michelmore, R. W., and Dubcovsky, J. 2011. Next generation sequencing provides rapid access to the genome of Puccinia striiformis f. sp. tritici, the causal agent of wheat stripe rust. PLoS One 6:e24230.

8. Cantu, D., Segovia, V., MacLean, D., Bayles, R., Chen, X., Kamoun, S., Dubcovsky, J., Saunders, D. G., and Uauy, C. 2013. Genome analyses of the wheat yellow (stripe) rust pathogen Puccinia striiformis f. sp. tritici reveal polymorphic and haustorial expressed secreted proteins as candidate effectors. BMC Genomics 14:270.

9. Cercueil, A., Bellemain, E., and Manel, S. 2002. PARENTE: Computer program for parentage analysis. J. Hered. 93:458-459.

10. De Backer, M., Alaei, H., Van Bockstaele, E., Roldan-Ruiz, I., van der Lee, T., Maes, M., and Heungens, K. 2011. Identification and characterization of pathotypes in Puccinia horiana, a rust pathogen of Chrysanthemum $\times$ morifolium. Eur. J. Plant Pathol. 130:325-338.

11. Dickens, J. S. W. 1968. The resistance of various cultivars and species of chrysanthemum to white rust (Puccinia horiana Henn.). Plant Pathol. 17:19-22.

12. Duplessis, S., Cuomo, C. A., Lin, Y. C., Aerts, A., Tisserant, E., VeneaultFourrey, C., Joly, D. L., Hacquard, S., Amselem, J. 1., Cantarel, B. L., Chiu, R., Coutinho, P. M., Feau, N., Field, M., Frey, P., Gelhaye, E., Goldberg, J., Grabherr, M. G., Kodira, C. D., Kohler, A., Kües, U., Lindquist, E. A., Lucas, S. M., Mago, R., Mauceli, E., Morin, E., Murat, C., Pangilinan, J. L., Park, R., Pearson, M., Quesneville, H., Rouhier, N., Sakthikumar, S., Salamov, A. A., Schmutz, J., Selles, B., Shapiro, H., Tanguay, P., Tuskan, G. A., Henrissat, B., Van de Peer, Y., Rouzé, P., Ellis, J. G., Dodds, P. N., Schein, J. E., Zhong, S., Hamelin, R. C., Grigoriev, I. V., Szabo, L. J., and Martin, F. 2011. Obligate biotrophy features unraveled by the genomic analysis of rust fungi. Proc. Natl. Acad. Sci. USA 108:9166-9171.

13. EPPO. 2004. Puccinia horiana. Bull. OEPP/EPPO 34:209-211.

14. Evanno, G., Regnaut, S., and Goudet, J. 2005. Detecting the number of clusters of individuals using the software STRUCTURE: A simulation study. Mol. Ecol. 14:2611-2620.

15. Falush, D., Stephens, M., and Pritchard, J. K. 2003. Inference of population structure using multilocus genotype data: Linked loci and correlated allele frequencies. Genetics 164:1567-1587.

16. Farris, J. S. 1969. On the cophenetic correlation coefficient. Syst. Biol. 18:279-285.

17. Firman, I. D., and Martin, P. H. 1968. White rust of chrysanthemums. Ann. Appl. Biol. 62:429-442.

18. Flor, H. H. 1956. The complementary genetic systems in flax and flax rust. Adv. Genet. 8:29-54.

19. Forche, A., Magee, P. T., Magee, B. B., and May, G. 2004. Genome-wide single-nucleotide polymorphism map for Candida albicans. Eukaryot. Cell 3:705-714.

20. Fournier, A., Widmer, F., and Enkerli, J. 2010. Development of a singlenucleotide polymorphism (SNP) assay for genotyping of Pandora neoaphidis. Fungal Biol. 114:498-506.

21. Gerber, S., Chabrier, P., and Kremer, A. 2003. FaMoz: A software for parentage analysis using dominant, codominant and uniparentally inherited markers. Mol. Ecol. Notes 3:479-481.

22. Goodnight, K. F., and Queller, D. C. 1999. Computer software for performing likelihood tests of pedigree relationship using genetic markers. Mol. Ecol. 8:1231-1234.

23. Gower, J. C. 1971. A general coefficient of similarity and some of its properties. Biometrics 27:857-871.

24. Hennings, P. 1901. Einige neue japanische Uredineen [Some new Japanese rusts]. Hedwigia 40:25-26

25. Hiratsuka, N. 1957. Three species of chrysanthemum rust in Japan and its neighboring districts. Sydowia 2:34-44.

26. Jones, O. R., and Wang, J. I. N. L. 2010. COLONY: A program for parentage and sibship inference from multilocus genotype data. Mol. Ecol. Resour. 10:551-555.

27. Kalinowski, S. T., Taper, M. L., and Marshall, T. C. 2007. Revising how the computer program CERVUS accommodates genotyping error increases success in paternity assignment. Mol. Ecol. 16:1099-1106.

28. Kapooria, R. G., and Zadoks, J. C. 1973. Morphology and cytology of the promycelium and the basidiospore of Puccinia horiana. Eur. J. Plant Pathol. 79:236-242.

29. Kim, S., Nikolaeva, E., Olson, T., and Kang, S. 2011. Overwintering of Chrysanthemum white rust caused by Puccinia horiana in Pennsylvania and challenges in its management. (Abstr.) Phytopathology 101:S91. 
30. Kohno, M., Nishimura, T., Ishizaki, H., and Kunoh, H. 1974. Teliospore germination and nuclear behaviors in Chrysanthemum white rust (Puccinia horiana P. Hennings). Bull. Fac. Agric. Mie Univ. 47:1-9.

31. Kohno, M., Nishimura, T., Ishizaki, H., and Kunoh, H. 1975. Nuclear behaviors during the process from teliospore stage through sporidial stage in two short-cycled rusts, Kuehneola japonica and Puccinia horiana. Bull. Fac. Agric. Mie Univ. 49:21-29.

32. Konovalov, D. A., Manning, C. L. I. N., and Henshaw, M. T. 2004. KINGROUP: A program for pedigree relationship reconstruction and kin group assignments using genetic markers. Mol. Ecol. Notes 4:779-782.

33. Leonard, K. J., and Szabo, L. J. 2005. Stem rust of small grains and grasses caused by Puccinia graminis. Mol. Plant Pathol. 6:99-111.

34. Mantel Nonparametric Test Calculator V2.0 1999. Australia: School of Natural Resource Sciences, Queensland University of Technology.

35. Luchi, N., Pratesi, N., Simi, L., Pazzagli, M., Capretti, P., Scala, A., Slippers, B., and Pinzani, P. 2011. High-resolution melting analysis: A new molecular approach for the early detection of Diplodia pinea in Austrian pine. Fungal Biol. 115:715-723.

36. Meudt, H. M., and Clarke, A. C. 2007. Almost forgotten or latest practice? AFLP applications, analyses and advances. Trends Plant Sci. 12:106-117.

37. Morin, P. A., Luikart, G., and Wayne, R. K. 2004. SNPs in ecology, evolution and conservation. Trends Ecol. Evol. 19:208-216.

38. Nagarajan, S., and Singh, D. V. 1990. Long-distance dispersion of rust pathogens. Annu. Rev. Phytopathol. 28:139-153.

39. Nicod, J.-C., and Largiad, C. R. 2003. SNPs by AFLP (SBA): A rapid SNP isolation strategy for non-model organisms. Nucleic Acids Res. 31:e19.

40. O'Keefe, G., and Davis, D. D. 2012. First confirmed report that Puccinia horiana, causal agent of chrysanthemum white rust, can overwinter in Pennsylvania. Plant Dis. 96:1381.

41. Ono, Y. 2002. The diversity of nuclear cycle in microcyclic rust fungi (Uredinales) and its ecological and evolutionary implications. Mycoscience 43:421-439.

42. Pinard, R., de Winter, A., Sarkis, G., Gerstein, M., Tartaro, K., Plant, R., Egholm, M., Rothberg, J., and Leamon, J. 2006. Assessment of whole genome amplification-induced bias through high-throughput, massively parallel whole genome sequencing. BMC Genomics 7:216.

43. Priest, M. J. 1995. Chrysanthemum white rust in New South Wales. Australas. Plant Pathol. 24:65-69.

44. Pritchard, J. K., Stephens, M., and Donnelly, P. 2000. Inference of population structure using multilocus genotype data. Genetics 155:945-959.
45. Rademaker, W., and de Jong, J. 1987. Types of resistance to Puccinia horiana in chrysanthemum. Acta Hortic. 197:85-88.

46. Shea, K. 2007. Cut flowers from countries with chrysanthemum white rust: Final rules. Rules Regul. Fed. Regist. 72:15805-15812.

47. Stokes, T. L., Kunkel, B. N., and Richards, E. J. 2002. Epigenetic variation in Arabidopsis disease resistance. Gene Dev. 16:171-182.

48. van Orsouw, N. J., Hogers, R. C. J., Janssen, A., Yalcin, F., Snoeijers, S., Verstege, E., Schneiders, H., van der Poel, H., van Oeveren, J., Verstegen, H., and van Eijk, M. J. T. 2007. Complexity reduction of polymorphic sequences (CRoPS): A novel approach for large-scale polymorphism discovery in complex genomes. PLoS One 2:1-10.

49. Velasco, R. G., Zavaleta-Mejia, E., Martinez, R. I. R., Mir, S. G. L., Davila, G. F., and Simpson, J. 2007. Pathogenic and molecular variability of Puccinia horiana Henn. isolates. Rev. Fitotec. Mex. 30:223-234.

50. Vittal, R., Yang, H.-C., and Hartman, G. 2012. Anastomosis of germ tubes and migration of nuclei in germ tube networks of the soybean rust pathogen, Phakopsora pachyrhizi. Eur. J. Plant Pathol. 132:163-167.

51. Vos, P., Hogers, R., Bleeker, M., Reijans, M., Vandelee, T., Hornes, M., Frijters, A., Pot, J., Peleman, J., Kuiper, M., and Zabeau, M. 1995. AFLP-A new technique for DNA-fingerprinting. Nucleic Acids Res. 23:4407-4414

52. Wang, X., and McCallum, B. 2009. Fusion body formation, germ tube anastomosis, and nuclear migration during the germination of urediniospores of the wheat leaf rust fungus, Puccinia triticina. Phytopathology 99:1355-1364.

53. Wang, Y., Zhu, M., Zhang, R., Yang, H., Wang, Y., Sun, G., Jin, S., and Hsiang, T. 2009. Whole genome amplification of the rust Puccinia striiformis f. sp. tritici from single spores. J. Microbiol. Methods 77:229234.

54. Whipps, J. M. 1993. A review of white rust (Puccinia horiana Henn) disease on chrysanthemum and the potential for its biological control with Verticillium lecanii (Zimm) Viegas. Ann. Appl. Biol. 122:173-187.

55. Wojdyla, A. T. 1999. Susceptibility of chrysanthemum cultivars to Puccinia horiana. Folia Hortic. 11:115-122.

56. Xu, J., Guo, H., and Yang, Z. L. 2007. Single nucleotide polymorphisms in the ectomycorrhizal mushroom Tricholoma matsutake. Microbiology 153:2002-2012.

57. Yamaguchi, T. 1981. Chrysanthemum breeding for resistance to white rust. Jpn. J. Breed. 31:121-132.

58. Zandvoort, R. 1968. Wind dispersal of Puccinia horiana. Eur. J. Plant Pathol. 74:124-127. 